\title{
Technical Note: Spring grazing preference of wheatgrass taxa by Rocky Mountain elk
}

\author{
THOMAS A. JONES, PHILIP J. URNESS, AND DALE C. NIELSON
}

\begin{abstract}
Authors are USDA-ARS, Forage and Range Research Laboratory, Utah State Univ., Logan, Ut. 84322-6300. Dep. of Rangeland Resources, Utah State Univ. and Utah Division of Wildlife Resources, Project W-105-R, Logan, Ut. 84322-5230.
\end{abstract}

\begin{abstract}
We measured the grazing preference of 3 castrated male Rocky Mountain elk (Cervus elaphus nelsoni) for 2 crested (Agropyron desertorum [Fischer ex Link] Schultes), 5 thickspike (Elymus lanceolatus ssp. lanceolatus [Scribner \& J.G. Smith] Gould), 3 Snake River (proposed name $E$. lanceolatus ssp. wawawaiensis), and 2 bluebunch wheatgrass (Pseudoroegneria spicata [Pursh] A. Löve) entries. Number of bites and visits were highly correlated in early May $\left(r^{2}=0.77\right)$ and late May $\left(r^{2}=0.83\right)$. 'Critana' and 'Elbee' thickspike and 'Hycrest' and 'Nordan' crested wheatgrasses can be recommended for seedings for elk spring grazing where these grasses are adapted.
\end{abstract}

Key Words: palatability, bluebunch wheatgrass, crested wheatgrass, thickspike wheatgrass, northern wheatgrass, Snake River wheatgrass.

Forage preferences of Rocky Mountain elk (Cervus elaphus nelsoni) are malleable (Kufeld 1973, Nelson and Leege 1982). Elk will consume primarily grass on grasslands and shrubs on shrublands, but prefer grass when both are available. Grasses and sedges can constitute over $85 \%$ of the diet in the spring. High utilization of grass may continue through the summer or grass may be supplemented or replaced in the diet by forbs, shrubs, or other woody plants. For example, elk in the Rocky Mountain region often prefer forbs during summer (Collins and Umess 1983).

Dietary selection by Rocky Mountain elk has been evaluated primarily in uncontrolled field settings. The literature reviews of Kufeld (1973) and Nelson and Leege (1982) report that elk prefer crested wheatgrasses (Agropyron cristatum [L.] Beauv., A. desertorum [Fischer ex Link] Schultes) and bluebunch wheatgrass ( $A$. spicatum $=$ Pseudoroegneria spicata $[$ Pursh] A. Löve) to thickspike wheatgrass (A. dasystachyum = Elymus lanceolatus ssp. lanceolatus [Scribner and J.G. Smith] Gould), although thickspike wheatgrass was evaluated only by Kirsch (1963). However, these comparisons might be misleading because they could not consider differences in preference among ecotypes within a species or control the relative abundance or availability of species (Kufeld 1973).

We know of no published work concerning elk preferences of grass taxa in a controlled setting. This type of study is preferred

Utah Agricultural Experiment Station Journal Paper 4475.

Manuscript accepted 21 September 1995. to determine which plants are desirable for elk habitat (Kufeld 1973, Schwartz and Hobbs 1985). A controlled setting makes it possible to select plant materials, equalize plant density, and rank preference inferred directly from bite-count data. Obtaining and utilizing captive animals discourages researchers from employing this experimental approach.

We conducted a controlled preference trial with Rocky Mountain elk involving 12 entries of 4 important wheatgrass taxa: the introduced crested wheatgrass, and the natives thickspike wheatgrass, Snake River wheatgrass (proposed name $E$. lanceolatus ssp. wawawaiensis), and bluebunch wheatgrass. The results will indicate which grass varieties might be preferred for seeding disturbed lands spring-grazed by elk.

\section{Materials and Methods}

Plants of 12 wheatgrass entries (named varieties or numbered experimental populations) were transplanted to a west-facing slope on a foothill site in Logan, Utah. The soil was a Sterling gravelly loam (loamy-skeletal, mixed, mesic Typic Calcixerolls [10-20\% slope]). Crested wheatgrasses were 'Nordan' and 'Hycrest'. Thickspike wheatgrasses were 'Elbee', 'Sodar', 'Critana', 'Bannock', and T-38 (Tuscarora, Nev.). Snake River wheatgrasses were 'Secar', K27 (Riggins, Ida.), and D38. Bluebunch wheatgrasses were the diploid 'Whitmar' and the tetraploid P7845 (Winchester, Ida.). All taxa are bunchgrasses except thickspike wheatgrass, which is highly rhizomatous.

Plants were established on $1-\mathrm{m}$ centers and were arranged so they could be separated by fences into 4 paddocks. Within each paddock were 18 blocks with 12 positions each. Each of the 12 positions in a block was randomly assigned to a plant of a specific entry. Thus each of the 4 paddocks consisted of $18 \times 12=216$ spaced plants $\left(216 \mathrm{~m}^{2}\right)$ surrounded by a fence and a border of Secar. We used 3 castrated male elk ranging in age from 8 to 15 years that had not been used in other experiments for 4 years. They had previously grazed on various sagebrush-grass sites, lodgepole pine and aspen forest types, and mountain brush communities at various locations in northern Utah.

Spring is the season when grass is consistently the most important portion of the elk's diet. Paddocks were grazed at 2 periods, early (1-3 May) and late May (21-23 May 1991), with 6 and 4 grazing sessions in each period, respectively. Our objective at the 3-day early May grazing period was to gather enough data to statistically separate entry means. Continued grazing exceeding 3 
days would alter the entries' morphology and forage availability, biasing data collection at the late May grazing period. Including several plants of each entry in each paddock and controlling length of the grazing period precluded bias because of differences in forage availability resulting from differential elk preference. Favorable weather conditions allowed the plants to grow quickly in this competition-free setting. Weather data were collected at the Utah State University weather station $1.6 \mathrm{~km}$ from the study site. Moisture totaling $45 \mathrm{~mm}$ was recorded 12 of the first 21 days of May. Three storm systems accounted for most of the precipitation during these 3 weeks, $28 \%$ (13 mm) on 3-5 May, 52\% (23 $\mathrm{mm}$ ) on 9-12 May, and 13\% (6 mm) on 18-19 May. During this time the daily high and low temperatures averaged $15^{\circ} \mathrm{C}$ (range 4 to $26^{\circ} \mathrm{C}$ ) and $4^{\circ} \mathrm{C}$ (range 0 to $9^{\circ} \mathrm{C}$ ), respectively.

Each of the 4 paddocks was grazed at least once in each grazing period, generally with 3 animals. Grazing sessions were conducted in the morning, afternoon, or evening, and averaged 63 min. A grazing session ended when the animals ceased to graze and began to ruminate. Observers assigned to each animal counted and recorded the number of bites taken from a particular plant. If the animal returned to the first plant after grazing another, the number of bites was recorded as an additional visit. To calculate the number of bites per plant, we determined the total number of bites taken from a particular entry by a single animal in a session. This number was divided by the number of extant plants of the entry (maximum of 18). Number of visits per plant was calculated as the number of discontinuous times an animal grazed an entry divided by the number of extant plants.

Each grazing session (mean of all animals in session) was considered a replication. Replications within grazing period (error a) were used to test for differences between grazing periods, the whole-plot effect, in a split-plot design. The residual error (error b) was used to test differences among entries, the split-plot effect, and the entry $X$ grazing period interaction. Entry means were separated by the Bayes L.S.D. (Waller-Duncan $k$-ratio $t$ test) with $k$ ratio $=100$ (Smith 1978).

Table 1. Bites per animal per session of 12 crested (CWG), thickspike (TSWG), Snake River (SRWG), and bluebunch (BBWG) wheatgrass entries at early (1-3 May) and late May (21-23 May 1991) grazing periods.

\begin{tabular}{lclc}
\hline \multicolumn{2}{c}{ Early May } & \multicolumn{3}{c}{ Late May } \\
\hline Entry & Bites/Session & Entry & Bites/Session \\
\hline & -- (no./plant) -- & & -- (no./plant) -- \\
Critana TSWG & $2.9 \mathrm{a}^{\mathrm{b}}$ & Critana TSWG & $3.6 \mathrm{a}$ \\
Elbee TSWG & $2.0 \mathrm{~b}$ & Nordan CWG & $3.1 \mathrm{ab}$ \\
Sodar TSWG & $1.6 \mathrm{bc}$ & Elbee TSWG & $3.1 \mathrm{ab}$ \\
Bannock TSWG & $1.4 \mathrm{bcd}$ & Hycrest CWG & $2.7 \mathrm{bc}$ \\
T-38 TSWG & $1.1 \mathrm{cde}$ & Sodar TSWG & $2.2 \mathrm{bc}$ \\
Hycrest CWG & $1.1 \mathrm{cde}$ & Bannock TSWG & $1.9 \mathrm{c}$ \\
Nordan CWG & $1.0 \mathrm{cde}$ & Whitmar BBWG & $0.8 \mathrm{~d}$ \\
Whitmar BBWG & $0.8 \mathrm{cde}$ & K27 SRWG & $0.7 \mathrm{~d}$ \\
K27 SRWG & $0.7 \mathrm{de}$ & Secar SRWG & $0.7 \mathrm{~d}$ \\
P7845 BBWG & $0.4 \mathrm{e}$ & P7845 BBWG & $0.5 \mathrm{~d}$ \\
D38 SRWG & $0.4 \mathrm{e}$ & T-38 TSWG & $0.5 \mathrm{~d}$ \\
Secar SRWG & $0.3 \mathrm{e}$ & D38 SRWG & $0.5 \mathrm{~d}$ \\
Bayes L.S.D. & 0.8 & & 1.0 \\
\hline
\end{tabular}

${ }^{3}$ Grazing period $X$ entry interaction significant $(P<0.01)$. Numbers of replications $n=17$ pind $n=12$ for early and late grazing periods, respectively.

Values within a column not followed by the same letter are significantly different according to the Waller-Duncan k-ratio t test (k ratio $=100)$.
Table 2. Visits per animal per session of 12 crested (CWG), thickspike (TSWG), Snake River (SRWG), and bluebunch (BBWG) wheatgrass entries at early (1-3 May) and late May (21-23 May 1991) grazing periods

\begin{tabular}{lclc}
\hline \hline \multicolumn{2}{c}{ Early May } & \multicolumn{2}{c}{ Late May } \\
\hline Entry & Visits/Session & \multicolumn{1}{c}{ Entry } & Visits/Session \\
\hline & -- (no./plant) - - & & -- (no./plant) - \\
Critana TSWG & $0.35 \mathrm{ab}$ & Nordan CWG & $0.54 \mathrm{a}$ \\
Elbee TSWG & $0.29 \mathrm{ab}$ & Hycrest CWG & $0.51 \mathrm{ab}$ \\
Hycrest CWG & $0.25 \mathrm{abc}$ & Critana TSWG & $0.48 \mathrm{ab}$ \\
Nordan CWG & $0.23 \mathrm{bc}$ & Elbee TSWG & $0.43 \mathrm{bc}$ \\
Bannock TSWG & $0.21 \mathrm{bcd}$ & Bannock TSWG & $0.34 \mathrm{~cd}$ \\
Sodar TSWG & $0.20 \mathrm{bcde}$ & Sodar TSWG & $0.28 \mathrm{de}$ \\
T-38 TSWG & $0.18 \mathrm{bcde}$ & K27 SRWG & $0.22 \mathrm{ef}$ \\
K27 SRWG & $0.17 \mathrm{bcde}$ & P7845 BBWG & $0.18 \mathrm{ef}$ \\
Whitmar BBWG & $0.16 \mathrm{cde}$ & Secar SRWG & $0.18 \mathrm{ef}$ \\
Secar SRWG & $0.10 \mathrm{de}$ & Whitmar BBWG & $0.17 \mathrm{ef}$ \\
P7845 BBWG & $0.08 \mathrm{e}$ & T-38 TSWG & $0.13 \mathrm{f}$ \\
D38 SRWG & $0.08 \mathrm{e}$ & D38 SRWG & $0.12 \mathrm{f}$ \\
Bayes L.S.D. & 0.12 & & 0.11 \\
\hline
\end{tabular}

${ }^{8}$ Grazing period $X$ entry interaction significant $(P<0.01)$. Numbers of replications $n=17$ and $n=12$ for early and late grazing periods, respectively.

${ }^{b}$ Values within a column not followed by the same letter are significantly different according to the Waller-Duncan k-ratio t test $(k$ ratio $=100)$.

\section{Results and Discussion}

Over 4,000 bites were recorded in 6 early May grazing sessions as well as 4 late May grazing sessions. Grazing period interacted with entry for number of bites $(\mathrm{P}<0.01)$, so results for the 2 grazing periods are presented separately. Elk preferred Critana thickspike wheatgrass at the early May grazing period, but Elbee thickspike and Nordan crested wheatgrasses were as preferred as Critana during late May (Table 1). Animals exhibited considerable selectivity, e.g., Critana received 10 and 7 times the number of bites of the least preferred entry at the early and late May grazing periods, respectively.

Number of visits was highly correlated with number of bites across entries $\left(r^{2}=0.77\right.$ for the early May and $r^{2}=0.83$ for the late May grazing periods). Again, there was a significant interaction between grazing period and entry $(\mathrm{P}<0.01)$, so results for the 2 grazing periods are presented separately (Table 2 ). Critana and Elbee thickspike wheatgrasses received the most visits at the early May grazing period, while Critana and the 2 crested wheatgrasses received the most visits at the late May grazing period. The highest-ranking Snake River or bluebunch wheatgrass entry never significantly exceeded the lowest-ranking entry in the test for number of bites or number of visits.

Perhaps the most noteworthy difference between the 2 grazing periods was that the 2 crested wheatgrasses were as preferred in number of bites as Critana and Elbee thickspike wheatgrasses at the late May, though not at the early May grazing period. This difference in preference may be due to differing phenological development of these 2 taxa. Thickspike wheatgrass matures consistently earlier than crested wheatgrass. Phenological differences would be accentuated at the late May grazing period. There was little reproductive growth at the early May grazing period relative to the late May period. Thus the greater number of bites taken of crested wheatgrass relative to Critana and Elbee at the late May grazing period was probably related to crested wheatgrass' rela- 
grazing period was probably related to crested wheatgrass' relatively vegetative state. Even though Critana and Elbee thickspike wheatgrasses were more mature at the late May grazing period, they were both still as preferred as at least 1 of the crested wheatgrasses.

Of the 10 native entries, elk preferred Critana and Elbee thickspike wheatgrasses for spring grazing. Critana is a bulk collection from north-central Montana and Elbee was developed from clones collected in the adjacent Canadian provinces of Alberta and Saskatchewan (Asay 1995). Hycrest and Nordan crested wheatgrasses were also preferred in late May. A mixture of thickspike and crested wheatgrasses for revegetation projects may be feasible. Differences in the maturity of these 2 grasses could facilitate a more uniform availability of forage through the spring. Furthermore, thickspike wheatgrass is rhizomatous and can spread into areas of poor initial establishment.

\section{Literature Cited}

Asay, K.H. 1995. Wheatgrass and wildryes: the perenial Triticeae, p. 373-394. In: R.F. Bames, D.A. Miller, and C.J. Nelson (eds.) Forages-an introduction to grassland agriculture (vol. 1). 5th ed. Iowa State Univ. Press, Ames, Iowa.

Collins, W.B. and P.J. Urness. 1983. Feeding behavior and habitat selection of mule deer and elk on northern Utah summer range. J. Wildl. Manage. 47:646-663.

Kirsch, J.B. 1963. Range use, relationship to logging, and food habits of the elk in the Little Belt Mountains, Montana. Unpublished thesis, Montana State Univ., Bozeman, Mon. 44 pp.

Kufeld, R.C. 1973. Foods eaten by the Rocky Mountain elk. J. Range Manage. 26:106-113.

Nelson, J.R. and T.A. Leege. 1982. Nutritional requirements and food habits, p. 323-367. In: J.W. Thomas and D.E. Toweill (eds.) Elk of North America: ecology and management. Stackpole Books, Harrisburg, Penn.

Schwartz, C.C. and N.T. Hobbs. 1985. Forage and range evaluation, p. 25-51. In: R.J. Hudson and R.G. White (eds.) Bioenergetics of wild herbivores. CRC Press, Boca Raton, Fla.

Smith, C.W. 1978. Bayes least significant difference: a review and comparison. Agron. J. 70:123-127.

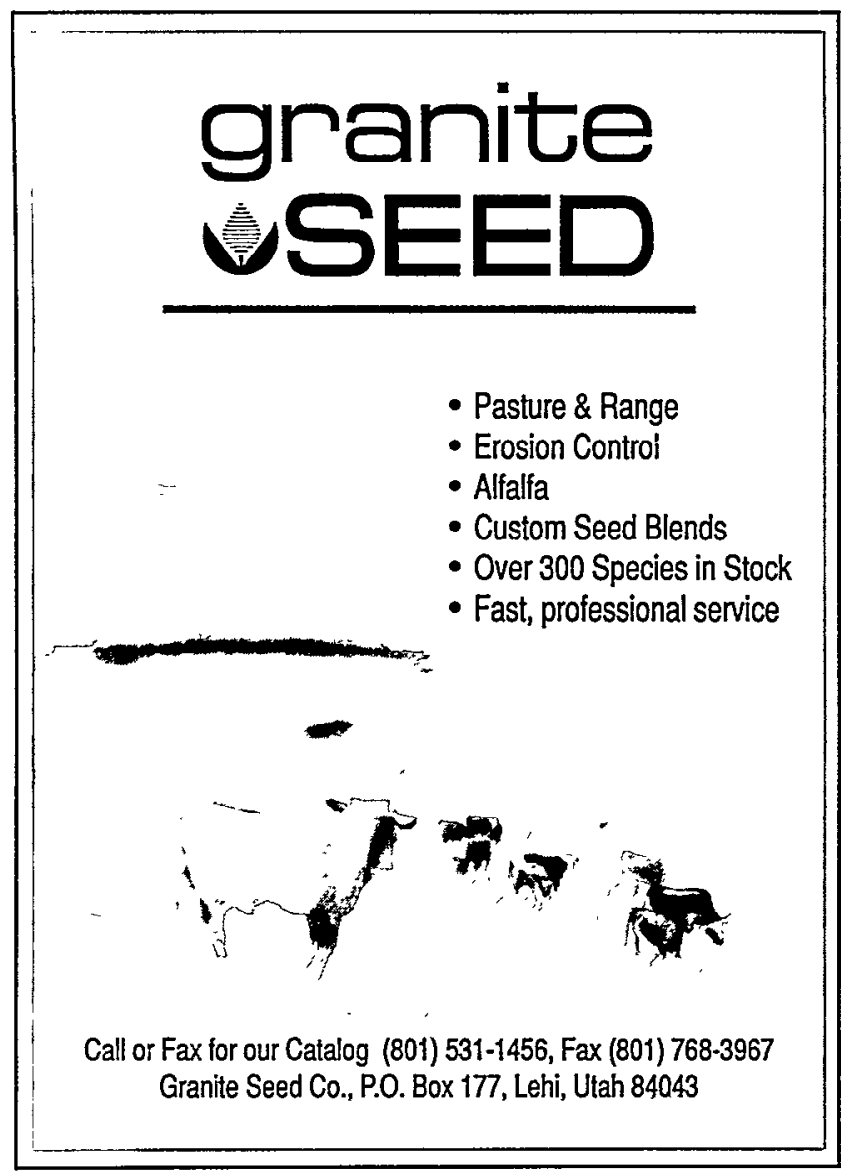

